\title{
Increasing the Genetic Base of Modern Cultivars of Eggplant of the Semi-Long Black Type
}

\author{
Maria HURTADO ${ }^{1}$, Santiago VILANOVA², Pietro GRAMAZIO², Mariola PLAZAS², Isabel ANDÚJAR², \\ Francisco Javier HERRAIZ², Jaime PROHENS ${ }^{*}$ \\ ${ }^{1}$ Meridiem Seeds S.L., Paraje Lo Soler 2, 30700 Torre Pacheco, Spain \\ ${ }^{2}$ Instituto de Conservación y Mejora de la Agrodiversidad Valenciana, Universitat Politècnica de \\ València, Camino de Vera 14, 46022 Valencia, Spain \\ *)Corresponding author, e-mail: jprohens@btc.upv.es
}

BulletinUASVM Horticulture 72(2) / 2015

Print ISSN 1843-5254, Electronic ISSN 1843-5394

DOI:10.15835/buasvmcn-hort:11663

\begin{abstract}
The eggplant (Solanum melongena) semi-long black varietal type is the most important in most European markets. Although open pollinated, pure lines and F1 hybrid cultivars exist within this varietal group, the latter predominate in the commercial production of eggplants, especially under greenhouse conditions. However, molecular markers studies have found that modern F1 hybrids present a reduced genetic base. This work is aimed at using a wide diversity of black eggplants for developing pure lines for obtaining hybrids heterotic for yield and increasing the genetic base of the black eggplants genepool. Thirty hybrid and non-hybrids varieties of black eggplants were used. Materials were characterized for morphological and agronomic traits of interest under greenhouse conditions. Molecular characterization was also performed using 16 SSR markers. A pedigree breeding programme was performed based on morphoagronomic traits until the F8 or F9 generations. Molecular analysis revealed that original materials could be separated in three main clusters groups, one made up by varieties from large companies that include the most successful varieties and the two other by an admixture of materials including non-hybrid varieties and F1 hybrids with moderate or low economic importance. The pedigree selection made allowed the final selection of 15 lines, which according to its origin, should have an increased genetic diversity compared to modern F1 hybrids. These lines, which present a very good performance under greenhouse conditions have been crossed in order to obtain hybrids heterotic for yield. These selected lines will be used to obtain a new generation of eggplant F1 hybrids with increased genetic base.
\end{abstract}

Keywords: genepool, hybrids, pedigree breeding, Solanum melongena, SSR markers.

\section{INTRODUCTION}

Eggplant (Solanum melongena L.) is very variable for fruit colour, size and shape. These differences are commonly used to establish the different cultivar groups (Daunay, 2008; MuñozFalcón et al., 2009). Fruit colour in eggplant is caused by the presence, distribution and amount of pigments in the epidermis, which are under the control of a few genes and QTLs and result in a wide diversity of colours (Daunay et al., 2004; Daunay, 2008; Cericola et al., 2014). The genetic control of fruit size and shape has also been studied and it has been found that a few major genes and QTL have a main role in determining fruit size and shape (Nunome et al., 2001; Portis et al., 2014). Also, an important fruit characteristic is calyx prickliness (Daunay, 2008). It has been found that a QTL in linkage group 6 plays a major role in prickliness of the different parts of the plant and fruit of eggplant (Frary et al., 2014; Gramazio et al., 2014)

In the European and Northamerican markets the most important varietal type is the black semilong eggplant (Daunay, 2008; Muñoz-Falcón et al., 2009). This type is characterized by presenting fruits of medium or large size (200-400 g), slightly obovate shape, intense black skin, and small calyx without prickles (Muñoz-Falcón et al., 
2009; Marín, 2015; Hurtado et al., 2013). Most commonly used cultivars of this type cultivated under highly productive conditions of Spain and other countries corresponds to F1 hybrids (Marín, 2015). Although local varieties and non-hybrid cultivars of this type are still grown in several areas of Spain, they are increasingly being replaced by F1 hybrids, which have been generally available since several decades ago (Marín 2007, Daunay, 2008). Commercial F1 hybrids have almost exclusively been developed by private breeding programmes, which allow exploiting heterosis for yield (Sambandam, 1964; Rodríguez-Burruezo et al. 2008) and also do not breed true, therefore contributing to the protection of the variety from illegal reproduction. In the case of the black semilong type, the development of F1 hybrids of the has been the result of selection of parental pure lines from a reduced genepool, which includes nonhybrid black varities like 'Black Beauty', 'Florida Market, and others (Savin, 1996; Daunay, 2008; Muñoz-Falcón et al., 2009).

Most commercial breeding programmes rely on developing pure lines from already existing commercial F1 hybrids. Although reliable protocols exist for obtaining doubled haploids in eggplant through androgenesis (Dumas de Vaulx and Chambonnet, 1982; Salas et al., 2012), developing pure lines directly from F1 hybrids is rarely used to obtain pure lines to be tested as potential parents for obtaining hybrids. The reason is that the frequency of pure lines with the desired characteristics or genotype is smaller than using a conventional method based on selfing and selection in each generation (Acquaah, 2012). In consequence, in comercial breeders normally develop pure lines in order to obtain hybrids using conventional methods based on selfing and selection. Androgenesis is mostly used to finally fix the selected materials in order to obtain completely homozygous materials that produce genetically uniform hybrids.

As a consequence of this common approach, the genetic diversity of the black semi-long F1 hybrids is becoming narrower, as it has been demonstrated with morphological and molecular markers (Muñoz-Falcón et al., 2009) which difficults the development of significantly improved new cultivars. On the contrary obsolete and non-hybrid varieties of the black type present a much higher genetic diversity (Muñoz-Falcón et al., 2009). Furthermore, a narrow genepool in the F1 hybrid genepool commonly used by breeders restricts the opportunities to exploit heterosis for yield resulting from obtaining hybrids from parents situated at a high genetic distance (Rodriguez-Burruezo et al., 2008). In this respect, in many other crops it has been demonstrated that broadening the genetic diversity in the genepool available to breeders has allowed considerable advances in the development of new improved cultivars (Cooper et al., 2001).

Our work was aimed at developing a breeding programme for the semi-long black type of eggplant in which new sources of diversity were included in order to broaden the genetic base of the genepool of this varietal type. The breeding programme has followed a pedigree scheme with phenotypic selection. Molecular markers have also been used to evaluate the diversity of the materials used for the breeding programme.

\section{MATERIALS AND METHODS}

Plant material. The starting plant material used consisted of thirty black eggplant varieties, of which 25 correspond to commercial F1 hybrids from different companies (Marín, 2015), including the most successful cultivars in the greenhouse vegetables production area of Almería (Southeast Spain), which is the most important in Spain (Torrellas et al., 2012), and 5 to non-hybrid varieties (Table 1). Some of the F1 hybrids varieties represent an élite genetic background, while others (those from the heirloom company Reimer) and the non-hybrid varieties were introduced in the programme in order to broaden the genetic diversity of the genepool and of the parental lines for obtaining commercial F1 hybrids. For the non-hybrid variaties crosses between them were used in order to develop F1 hybrids on which to start the selection programme. The varieties were transplanted to a greenhouse in Almería using a randomized block design, with five replicates (each with three plants) per variety.

For the rest of generations used in the breeding programme, a variable number of plants was used, ranging from 1200 to 1500 for each selection cycle. In these generations, in order to facilitate selection of all plants of a certain family, they were grown together in the same plot. Controls, consisting of F1 starting materials dominant in the market were 
included for comparisons in the generations in which selection was performed.

Morphological characterization. A morphological characterization was performed based on agronomic and fruit traits of importance for the market in this varietal type: yield, fruit set under greenhouse conditions, fruit set recovery, fruit size and its uniformity, fruit shape and its uniformity, calyx size, calyx prickliness, skin colour and brightness. The ideotype was defined as a plant with high yield, good fruit set under greenhouse conditions, good fruit set recovery, intermediate fruit size with high uniformity, semi- long slightly obovate shape with highly uniform fruits, small calyx size, no calyx prickliness, intense black colour that does not fade, and high skin brightness.

Molecular characterization. Genomic DNA was extracted from young leaves using the CTAB method (Doyle and Doyle, 1987) with some modifications. DNA quantitation was performed with a Nanodrop ND-1000 (Nanodrop Technologies, Wilminton, DE, USA) spectrophotometer, which allowed determining the DNA concentration and the absorbance ratios $260 / 280 \mathrm{~nm}$ and $260 / 230 \mathrm{~nm}$, which provide

Tab. 1. Varieties included as starting materials for the breeding programme, including the code used in the present work,

\begin{tabular}{|c|c|c|c|}
\hline Code & Variety & Seed company & Type of material \\
\hline 102 & Sultana & Batlle & F1 hybrid \\
\hline 103 & Calanda & Ramiro Arnedo & F1 hybrid \\
\hline 104 & Mulata & Ramiro Arnedo & F1 hybrid \\
\hline 105 & AR04040 & Ramiro Arnedo & F1 hybrid \\
\hline 106 & Fantastic & Rijk Zwaan & F1 hybrid \\
\hline 107 & Monarca & Rijk Zwaan & F1 hybrid \\
\hline 108 & PX02326549 & Petoseed & F1 hybrid \\
\hline 109 & Petra & Fitó & F1 hybrid \\
\hline 110 & Cristal & Fitó & F1 hybrid \\
\hline 111 & Bellezza Nera & Vilmorin & Non-hybrid \\
\hline 112 & De Barbentane & Vilmorin & Non-hybrid \\
\hline 114 & Redonda Negra Lisa & F. Garden & Non-hybrid \\
\hline 115 & Larga Negra & Ramiro Arnedo & Non-hybrid \\
\hline 116 & LF3-24 & INRA & Non-hybrid \\
\hline 117 & Black Bell & Petoseed & F1 hybrid \\
\hline 118 & Birga & Petoseed & F1 hybrid \\
\hline 119 & Black Moon & Asgrow & F1 hybrid \\
\hline 120 & Tasca & Vilmorin & F1 hybrid \\
\hline 121 & Rendia & De Ruiter & F1 hybrid \\
\hline 122 & Risorsa & Vilmorin & F1 hybrid \\
\hline 123 & Brigitte & Rijk Zwaan & F1 hybrid \\
\hline 124 & Longo & Rijk Zwaan & F1 hybrid \\
\hline 125 & Money Maker & Reimer & F1 hybrid \\
\hline 126 & Edna & Reimer & F1 hybrid \\
\hline 127 & Millionaire & Reimer & F1 hybrid \\
\hline 128 & Vittoria & Reimer & F1 hybrid \\
\hline 129 & Nadia & Reimer & F1 hybrid \\
\hline 130 & Night Shadow & Reimer & F1 hybrid \\
\hline 131 & Dusky & Reimer & F1 hybrid \\
\hline 132 & Epic & Reimer & F1 hybrid \\
\hline
\end{tabular}


an indication of DNA quality (Heptinstall and Rapley, 2000). In order to analyze DNA integrity we performed an electrophoresis in agarose gel at $1 \%$ and staining with ethidium bromide $(0.8 \mathrm{mg} /$ $\mathrm{ml}$ ) and the bands were visualized with ultraviolet light in a transilluminator.

For the molecular analysis we used 16 genomic SSRs (Vilanova et al., 2012), which weew amplified by PCR using a PCR System 2700 Gene Amp (Applied Biosystems, Foster City, CA, USA) thermal cycler. Once the PCR reactions had been performed, amplifications were verified in an agarose (2\%) gel using $2 \mathrm{ml}$ of the PCR sample, 2 $\mathrm{ml}$ of bromophenol blue and $6 \mathrm{ml}$ of milliQ $\mathrm{H}_{2} \mathrm{O}$. The analysis of the PCR products was performed using an ABI PRISM 3100-Avant (Applied Biosystems) automatic fragment analyzer. An UPGMA phenogram was obtained using Dice genetic distances.

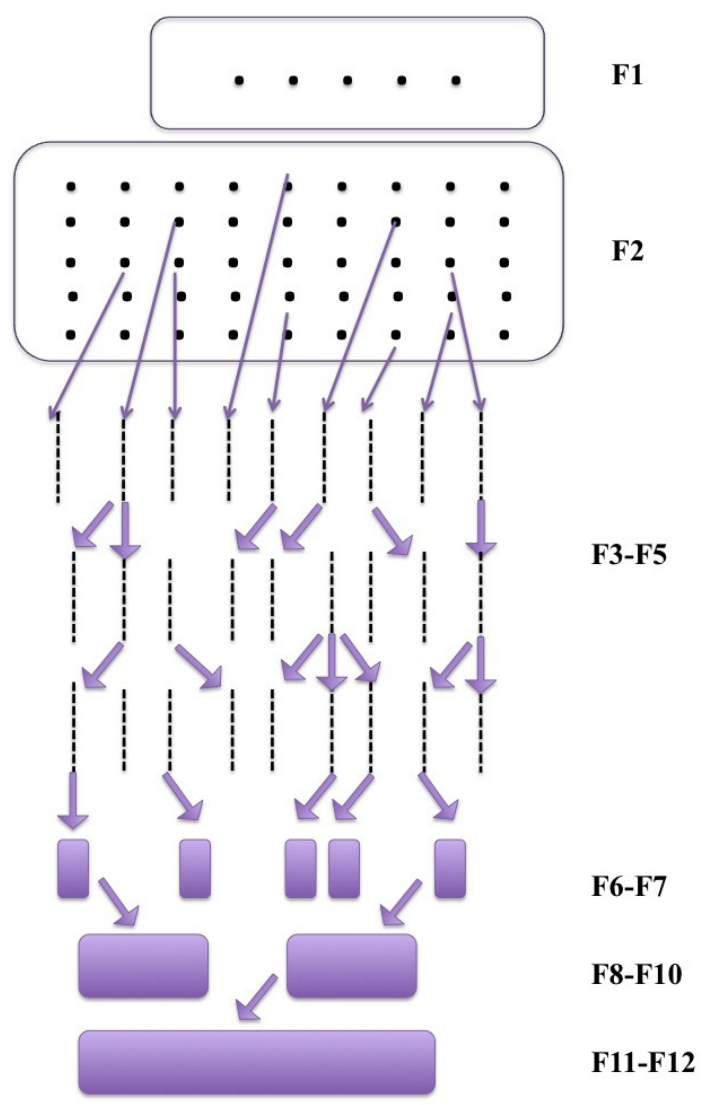

Fig. 1. Scheme of the pedigree method used for the selection of pure lines to be used as parents for developing new eggplant hybrids of the black semilong type. Each generation corresponds to the selfing of selected individuals of the preceeding generation.
Selection methodology. In order to develop pure lines for obtaining hybrids, we used the pedigree method (Fig. 1), based in selecting the best individuals in the F2 and then the best progenies and best individuals within each progeny (Acquaah, 2012). Seed obtained after selfing of the best individuals was used in order to obtain subsequent generations, up to the F8 generation. Traits used for selection were those indicated in the morphological characterization subsection. Molecular data were also considered in order to conserve a high diversity among the selected materials.

\section{RESULTS AND DISCUSSION}

Many differences were found among the original varieties in their performance for the traits studied. In general F1 hybrids performed better than the non-hybrid varieties, with the former varieties generally having higher yield and fruit set tan non-hybrid varieties. This result was expected, as most of the F1 hybrid varieties had been selected for greenhouse conditions, while the non-hybrid varieties include several varieties for open field cultivation (Marín, 2015). Given the important differences among greenhouse and open field cultivation in eggplant (Stommel et al., 2015) F1 hybrids represent an élite germplasm with specific adaptation to the greenhouse conditions

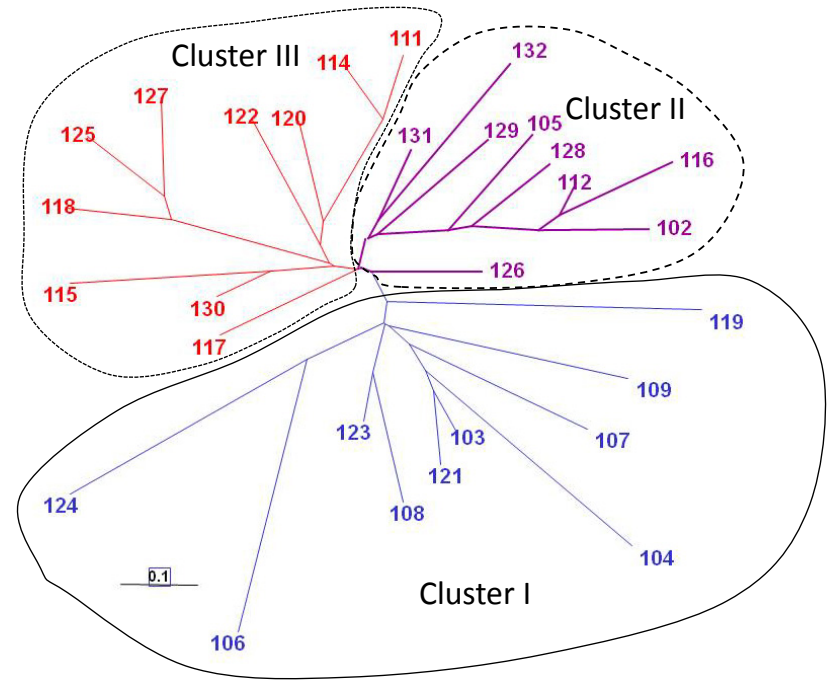

Fig. 2. UPGMA cluster analysis based and Dice genetic distance of genotyping data of 16 SSR markers. The three major clusters (I, II and III) have been indicated by lines of different typologies: cluster I (continuous line), cluster II (dashed line), cluster III (pointed line). 
that include cultivation under reduced luminosity and cooler temperatures when compared to the typical cultivation conditions during the summer in the open field (Baixauli, 2001; Muñoz-Falcón et al., 2009).

The molecular analysis of the thirty varieties used as starting material revealed that the materials were genetically diverse and differentiated into three major clusters (Fig. 2). One of the major clusters (cluster I) includes varieties from the major seed companies in eggplant seed marketing in southeastern Spain, like Asgrow, De Ruiter, Fitó, Petoseeds, Ramiro Arnedo, and Rijk Zwaan. These materials are the most extensively grown and have the greatest cost per seed (Marín, 2015). This is in agreement with the results obtained by MuñozFalcón et al. (2009), who using molecular markers, found that hybrids from major seed companies clustered together. No materials of the local varieties or from the small seed company Reimer are included in this cluster (Fig. 2), suggesting that modern greenhouse hybrids have an élite and differentiated genetic background. The results obtained from the morphological characterization also indicate that the F1 hybrids from cluster I are differentiated from the rest of varieties for having a larger and less elongated fruit than the rest of modern hybrids.

The two other major clusters (II and III) also contain a few modern hybrids not included in the cluster I, and which generally are not among the predominant cultivars, all the non-hybrid cultivars, and all the hybrids from Reimer company (Fig. 2). The hybrids of this latter company are generally recommended for open field cultivation. Amazingly, the two hybrids and the two non-hybrid varieties of Vilmorin are included in these two clusters. The eight hybrid varieties of Reimer seeds are very variable and are distributed in different branches in the clusters II and III. This is probably due to the fact that these hybrids include materials from the Occidental and Oriental genepools of eggplant (Vilanova et al., 2012). When compared with morphological traits, varieties 118 (Birga, from Petoseeds), 125 (Money Maker, from Reimer Seeds) and 127 (Millionaire, from Reimer Seeds), which are situated in the same branch of cluster III, are the only ones which present anthocyanins in the calyx. The presence of anthocyanins in the calyx is controlled by four QTL, of which three are in linkage group 10 (Cericola et al., 2014). This suggests that their common genetic background may arise from having taken this characteristic from the same source.

Overall, the results of characterization of the parents indicates that there is ample genetic diversity in the genepool of the black semilong type of eggplant, and this could be used to increase the genetic diversity of modern cultivars of this type. This may contribute to increase the heterosis of F1 hybrids by crossing genetically distant parents (Rodríguez-Burruezo et al., 2008), as well as to increase the morphological diversity (e.g., calyx with anthocyanins, smaller fruits, etc.) of modern F1 hybrids.

From the selfed progenies of each F1 hybrid, genealogical selection was performed using the target traits and selecting only those plants
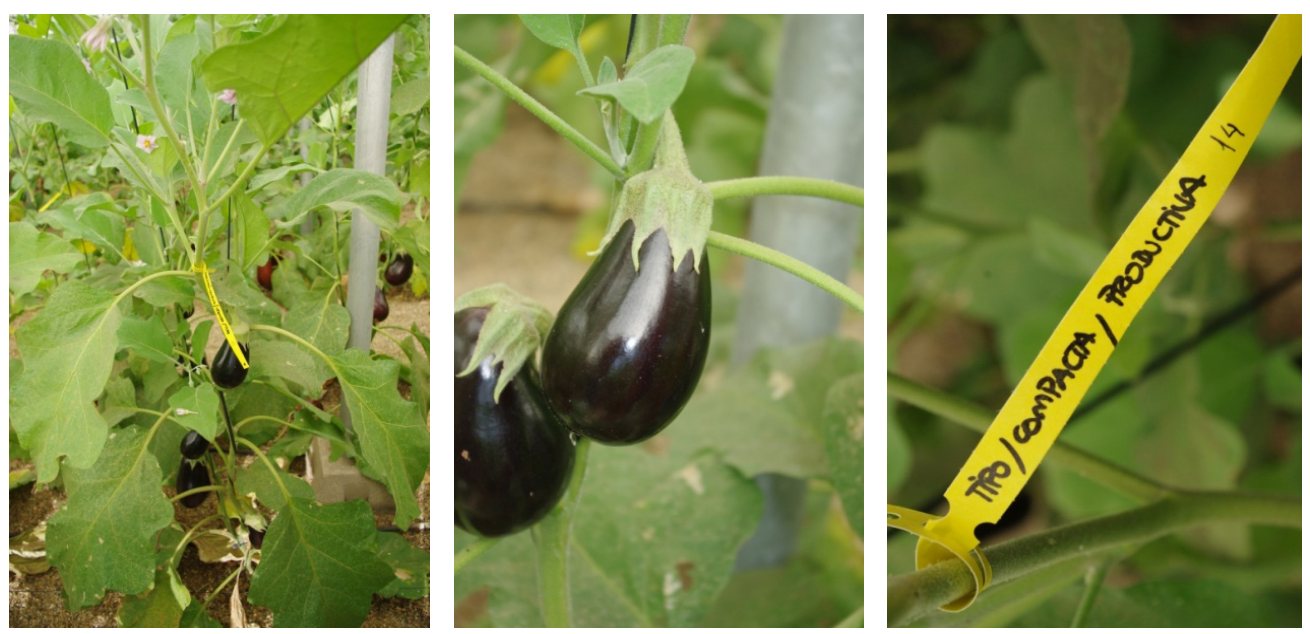

Fig. 3. One example of selected line, with a morphotype similar to the desired ideotype, and the way of tagging the plant. 
with better characteristics using a conventional pedigree selection scheme (Acquaah, 2015). In each generation, the selection was performed taking into account that a considerable genetic diversity, considering their provenance, was maintained (Fig. 3).

This selection method resulted in that the morphotype of the selected materials in each generation was becoming more similar to the desired ideotype, as defined in Material and Methods, and more uniform, as the heterozygosis was reduced by one half in each generation of selfing. After subsequent selfing generations a total of 15 lines have been selected in the F8F9 generations. These materials originate from different materials out of the thirty originally used, including varieties from each of the three clusters. Therefore, a large diversity is expected in these set of selected lines. Each of these lines is highly uniform and they are going to be genotyped and hybridized using a crossing-block scheme (Acquaah, 2015) in order to obtain the first hybrids, which will be used to select the most interesting for the market. Also, this fisrt set of hybrids will be used to evaluet the general combining ability of the different parental lines and the relationship between genetic distance and heterosis in these materials.

\section{CONCLUSION}

The methodology used, based in the use of molecular markers to select parents that represent an extended diversity compared to modern varieties combined with pedigree breeding has allowed developing phenotypically excellent pure lines of the black semi-long type of eggplant. These lines will be used to obtain a new generation of eggplant F1 hybrids with increased genetic base, effectively contributing to broadening the genepool of modern commercial F1 hybrids of eggplant.

Acknowledgments. This research has been partially funded by Meridiem Seeds and by Ministerio de Economía y Competitividad and FEDER (grant AGL2012-34213). Isabel Andújar and Pietro Gramazio are grateful to Universitat Politècnica de València (Programa de Ayudas de Investigación y Desarrollo, PAID) for a postdoctoral and predoctoral contract, respectively.

\section{REFERENCES}

1. Acquaah G (2012). Principles of plant breeding, $2^{\text {nd }}$ ed. Wiley-Blackwell, Oxford, UK.

2. Baixauli C (2001). Berenjena, p. 104-108. In Nuez F, Llácer G (Eds.). La horticultura española. Ediciones de Horticultura, Reus, Spain.

3. Cericola F, Portis E, Lanteri S, Toppino L, Barchi L, Acciarri N, Pulcini L, Sala T, Rotino GL (2014). Linkage disequilibrium and genome-wide association analysis for anthocyanin pigmentation and fruit color in eggplant. BMC Genomics 15:896.

4. Cooper HD, Spillane C, Hodgkin T (2001). Broadening the genetic base of crop production. CABI, Wallingford, UK.

5. Daunay MC (2008). Eggplant, p. 163-220. In Prohens J, Nuez F (Eds.). Handbook of plant breeding: Vegetables II. Springer, New York.

6. Daunay MC, Aubert S, Frary A, Doganlar S, Lester RN, Barendse G, van der Weerden G, Hennart IW, Haanstra J, Dauphin F, Jullian E (2004). Eggplant (Solanum melongena) fruit colour, pigments, measurements and genetics, p. 108-116. In Voorrips RE (Ed.). Proceedings of the $\mathrm{XI}^{\text {th }}$ Meeting on Genetics and Breeding of Capsicum and Eggplant. Plant Research International, Noordwijkerhout, The Netherlands.

7. Dumas de Vaulx R, Chambonnet D (1982). In vitro culture in eggplant (Solanum melongena L.). Stimulation of plant production by means of treatments at $35^{\circ} \mathrm{C}$ combined with low concentrations of growth substances. Agronomie 2:983-988.

8. Frary A, Frary A, Daunay MC, Huvenaars K, Mank R, Doganlar S (2014). QTL hotspots in eggplant (Solanum melongena) detected with a high resolution map and CIM analysis. Euphytica 197:211-228.

9. Gramazio P, Prohens J, Plazas M, Andújar I, Herraiz FJ, Castillo E, Knapp S, Meyer R, Vilanova S (2014). Location of chlorogenic acid biosynthesis pathway and polyphenol oxidase genes in a new interspecific anchored linkage map of eggplant. BMC Plant Biol 14:350.

10. Heptinstall J, Rapley R (2000). Spectrophotometric analysis of nucleic acids, p. 57-60. In Rapley R (Ed.). The nucleic acid protocols handbook. Humana Press, Totowa, NJ. USA.

11. Hurtado M, Vilanova S, Plazas M, Gramazio P, Herraiz FJ, Andújar I, Prohens J (2013). Phenomics of fruit shape in eggplant (Solanum melongena L.) using Tomato Analyzer software. Sci Hort 164:625-632.

12. Marín J (2015). Portagrano: vademecum de semillas variedades hortícolas, José Marín Rodríguez, El Ejido, Spain.

13. Muñoz-Falcón JE, Prohens J, Vilanova S, Nuez F (2009). Diversity in commercial varieties and landraces of black eggplants and implications for broadening the breeders' gene pool. Ann Appl Biol 154:453-465.

14. Nunome T, Ishiguro K, Yoshida T, Hirai M (2001). Mapping of fruit shape and color development traits in eggplant (Solanum melongena L.) based on RAPD and AFLP markers. Breed Sci 51:19-26. 
15. Portis E, Barchi L, Toppino L, Lanteri S, Acciarri N, Felicioni N, Fusari, F, Barbierato V, Cericola F, Valè G, Rotino GL (2014). QTL mapping in eggplant reveals clusters of yieldrelated loci and orthology with the tomato genome. PLOS ONE 9:e89499.

16. Rodríguez-Burruezo A, Prohens J, Nuez F (2008). Performance of hybrids between local varieties of eggplant (Solanum melongena) and its relation to the mean of parents and to morphological and genetic distances among parents. Eur J Hort Sci 73:76-83.

17. Salas P, Rivas-Sendra A, Prohens J, Seguí-Simarro JM (2012). Influence of the stage for anther excision and heterostyly in embryogenesis induction from eggplant anther cultures. Euphytica 184:235-250.
18. Samdanbam (1964). Heterosis in eggplant. Ec Bot 18:128131.

19. Savin F (2006). L'aubergine dans le basin mediterranéen (hors Turquie). PMH Rev Hort 374:50-52.

20. Stommel JR, Haynes KG, Whitaker BD, Prohens J (2015). Genotype $\mathrm{x}$ environment interactions in eggplant for fruit phenolic acid content. Euphytica:in press.

21. Torrellas M, Antón A, Ruijs M, Victoria NG, Stanghellini C, Montero JI (2012). Environmental and economic assessment of protected crops in four European scenarios. J Cleaner Prod 28:45-55. 